of connective tissue (dotted line Fig. 1A). An annular pancreas results from a defect in rotation of the ventral primordium towards the dorsal pancreatic bud [3]. The fact that all the abnormally-developed tissue showed a distinct pancreatic polypeptide immunofluorescence proves the hypothesis that the ventral primordium is the origin of the pancreatic tissue rich in pancreatic polypeptide. However, the reason for the differing pancreatic polypeptide and glucagon contents of the two primordia remains to be established.

Yours sincerely,

Y.Stefan, S. Grasso, A. Perrelet and L. Orci

\section{References}

1. Orci L, Malaisse-Lagae F, Baetens D, Perrelet A (1978) Pancreaticpolypeptide-rich regions in human pancreas. Lancet II: 1200-1201

2. Malaisse-Lagae F, Stefan Y, Cox J, Perrelet A, Orci L (1979) Identification of a lobe in the adult human pancreas rich in pancreatic polypeptide. Diabetologia 17: 361-365

3. Langman J (1981) Medical embryology, 4th ed. Williams and Wilkins, Baltimore, pp 220-222

4. Malaisse-Lagae F, Orci L, Perrelet A (1979) Anatomic and hormo- nal markers for the ventral primordium in the human pancreas? N Engl J Med 300: 436

5. Rahier J, Wallon J, Gepts W, Haot J (1979) Localization of pancreatic polypeptide cells in a limited lobe of the human neonate pancreas: remnant of the ventral primordium? Cell Tiss Res 200: 359-366

6. Paulin C, Dubois PM (1978) Immunohistochemical identification and localization of pancreatic polypeptide cells in the pancreas and gastrointestinal tract of the human fetus and adult man. Cell Tiss Res 188: 251-257

7. Coons H, Leduc E, Connolly J (1955) Studies on antibody production. I. A method for the histochemical demonstration of specific antibody and its application to a study of the hyperimmune rabbit. J Exp Med 102: 49-60

\section{Orci}

Institute of Histology and Embryology

University of Geneva Medical School

CH-1211 Geneva 4, Switzerland

S. Grasso

Institute of Pathology

University of Catania

Catania, Italy

\title{
Exercise-Induced Proteinuria in Diabetic Children
}

\section{Dear Sir}

The November 1981 issue of Diabetologia contained an article on exercise-induced proteinuria in children with Type 1 (insulin-dependent) diabetes [1]. In view of the results of studies on exercise proteinuria obtained in our laboratory, it would seem likely that the use of a radioimmunoassay as a means of estimating glomerular permeability in early diabetes may be providing correct, but less than optimal, information.

Polyacrylamide gel electrophoresis studies on the nature of the urinary proteins excreted after light exercise have shown that adolescent girls with normal renal function may excrete proteins of molecular weight as large as $170,000-215,000$ daltons [2]. We have found similar size proteins in the pre-exercise urines of gymnasts, physical education students and rugby football players (unpublished observations). These findings have led us to conclude that, during everyday activities, large plasma proteins may pass through the glomerular filter. Such temporary increases in glomenular permeability are enhanced during exercise and the high molecular weight proteinuria will be associated with increased urinary protein concentration.

We have found that the urinary protein profiles of patients with the nephrotic syndrome are not very different from the post-exercise urinary protein profiles of healthy young athletes. Urine from diabetic patients, studied by the same technique, showed similar protein profiles to some post-exercise samples, but in those cases where the ESR was raised the urine contained larger plasma proteins. From this point of view, the difference between exercise proteinuria and pathological proteinuria appears to be the persistence and chronicity of the latter.

Recently I have proposed that increased blood viscosity is an important factor in the mechanism of proteinuria and capillary leakage [3]. As it has been well demonstrated that diabetic patients with poor metabolic control have increased blood viscosity, it is probable that, in circumstances where blood viscosity was even slightly increased, the intra-renal vascular changes associated with exercise would result in proteinuria. However if the excretion of albumin alone was being monitored then the significance of the proteinuria might be missed. It seems likely that those diabetic patients with raised basal urinary albumin levels who showed marked increase in albuminuria after exercise [4] also had raised blood viscosities. As normalisation of blood viscosity occurs when good metabolic control is restored in diabetes, the removal of the cause of chronic proteinuria will not prevent temporary high molecular weight proteinuria occurring after athletic activity.

In order to utilise recently published information in the fields of exercise proteinuria and haemorheology, I would suggest that, where possible, studies of 'diabetic' proteinuria should include investigations into low shear rate blood viscosity.

Yours sincerely

L. O.Simpson

\section{References}

1. Huttunen N-P, Kaar M-L, Puukka R, Akerblom AK (1981) Exercise-induced proteinuria in children and adolescents with Type 1 (insulin-dependent) diabetes. Diabetologia 21: 495-497

2. Simpson LO, Shand BI (1981) Proteinuria induced by light exercise. Proc Univ Otago Med Sch 59: 98-99

3. Simpson LO (1982) A hypothesis proposing increased blood viscosity as a cause of proteinuria and increased vascular permeability. Nephron (in press)

4. Mogensen CE, Vittinghus E, Solling K (1979) Abnormal albumin excretion after two provocative renal tests in diabetes: physical exercise and lysine injection. Kidney Int 16: 385-393

\section{O.Simpson}

Department of Pathology

University of Otago Medical School

Dunedin, New Zealand 